Article

\title{
Optimal Conditions of Membrane Filtration Process in the Treatment of Blending Water by Lab-Scale and Pilot-Scale Tests
}

\author{
Sung-joon Kim ${ }^{1, *}$ \\ 1 Department of Environmental Engineering, Division of Civil, Environmental, Mineral Resource and Energy \\ Engineering, Chonbuk National University, 567 Baekje-daero, Deokjin-gu, Jeonju 54896, Korea; \\ ksjduck0505@gmail.com (S.J.K.) \\ * Correspondence: ksjduck0505@gmail.com (S.J.K.); Tel.: +82-10-4650-3117 ; Fax: +82-63-270-2449
}

\begin{abstract}
The aim of this study is to evaluate the optimal conditions of membrane filtration process. Both laboratory test and pilot-scale test were conducted to examine a treated water on blending water. The water sample were prepared by blending a raw water and the effluent water filtered through an organic membrane. The optimal efficiency in the treatment of water quality at the lab-scale test was generated under conditions of flux at $2.0 \mathrm{~m}^{3} / \mathrm{m}^{2}$.day, the blending ratio of $4: 1$, and the optimal dosage of coagulant at $20 \mathrm{ppm}$. The pilot-scale test resulted in that the optimal efficiency was obtained under conditions of flux at $2.0 \mathrm{~m}^{3} / \mathrm{m}^{2}$.day and the blending ratio of $6.0: 1$. However, the different results between lab-scale and pilot-scale tests on the optimal dosage of coagulant implied that it is difficult to achieve the stable condition of process operation at the low level of coagulant. In summary, the results indicated that, in the combination process of organic membrane and ceramic membrane, the recovery efficiency was achieved above the level of $98.4 \%$. Compared to $92.1 \%$ in a single organic membrane process, the combination process is $6.3 \%$ more efficient than the single one. This combination process of water treatment lead to stable recovery rates by the optimal input of dosage, less pollution load to water, and a stabilized filtration system.
\end{abstract}

Keywords: ceramic membrane; combination process; microfiltration; optimization; recovery efficiency

\section{Introduction}

Water quality has kept deteriorating originated from agricultural residues, sewage and industrial wastewater [1,2]. Securing clean water is one of the challenges to be overcome globally $[3,4]$. Research has been conducted in various ways to meet the increasing demand of safe water: such as, technological advances, water reuse, desalination of seawater $[5,6]$.

It is important for the human needs to have purification methods for drinking water. Removal of natural organic matter (NOM) is a major issue for the production process of drinking water [7]. NOM includes residues of microalgae, plants and microorganisms as well as dissolved organic matter (DOM) consisting of fulvic acids, humic acids, molecular weight organics, polysaccharides and biopolymers [7].

Such substances addressed ahead are generally quantified by DOC (dissolved organic carbon) [8]. DOC compositions vary widely in surface water. UV absorbance at $254 \mathrm{~nm}\left(\mathrm{UV}_{254}\right)$ represent humic substances including double bond and benzene ring [9]. Specific ultraviolet absorbance 254 (SUVA 254 ) yields a quantitative estimate of aromatic content per unit concentration of organic carbon [10]. In addition, drinking water requires high level of clarity and very low turbidity [11]. 
In order to achieve the high standard of drinking water quality, membrane technology is possibly proposed as a strong method [12]. Recently membrane technology has become more economically sound, according to the growth of using membrane filtration technology $[1,9,13,14]$. Membrane technology for water treatment is known as microfiltration(MF), ultrafiltration, nanofiltration, reverse osmosis, forward osmosis, membrane distillation, electro dialysis, and pervaporation [1]. They have been classified according to process and purpose of water treatment system.

In particular, MF treatment an important role in treating surface water for the purpose of drinking water security [15-17]. Organic membranes used for drinking water treatment are relatively inexpensive, and many studies have been conducted and widely used for reverse osmosis, pervaporation [18-20]. However, it is difficult to sustain the use of organic membrane due to the following problems that include a decrease of quality in membrane permeability, an increase of cleaning times, and a decrease of lifespan [21]. Such disadvantages are main obstacles in application to drinking water treatment processes. In contrast, ceramic membranes have advantages over organic membranes; for example, mechanical resistance, pressure resistance, long service lifespan, chemical inertness, thermal stability, and easy rinsing [22-26].

In addition, a process utilizing blending of raw water and treated water has been proposed to reuse waste water to drinking water [27]. Blending also dilute pollutants in water so that it is an important treatment method for drinking water sensitive to pollutants. Water utilities typically should meet the seasonal demand, or decrease in reliance on raw water. There are multiple sources of water, and it is important to comply with drinking water guidelines [27,28]. Optimizing the blending ratio of water from different sources may minimize the overload of a raw water. An optimization method is needed to achieve an appropriate blending ratio. In this way, it can contribute to improving the recovery efficiency of raw water in the purification plant [29].

This study aims to evaluate the processing performance of ceramic membrane in order to ensure continuous drinking water from blending water. Lab-scale study was processed to confirm the optimal dosage of coagulant and a blending ratio, and to demonstrate the optimal efficiency in the treatment of the ceramic membrane. In addition, the pilot-scale shows the recovery efficiency through the combination process of organic and ceramic membrane filters. Based on lab, pilot-scale is proceeded to suggest the optimal process for the membrane process and field application.

\section{Materials and Methods}

\subsection{MF membrane set-up and operational control for lab and pilot-scale}

Raw water samples were collected from Y Dam in Korea, and backwashing water was obtained from $\mathrm{G}$ water purification plant (J city, Korea). The pilot-scale plant was built up near the location of $\mathrm{G}$ water purification plant. Table 1 presents the properties of the MF membranes used for both laboratory-scale and pilot-scale tests. The schematic diagram according to the composition of the experiment is shown in Fig.S1 and Fig. S2. Properties of raw water and back-washing water are shown in Table 2. Treated water sample was prepared by blending a raw water with a backwash water filtered through organic membrane. From the process of blending water samples, it is possible to find out the performance of ceramic membrane and the optimum blending ratio. We prepare blending water samples in lab-scale test at a constant ratio. However, the pilot-scale showed a slight difference in blending in contrast to the lab-scale. Difficulties in blending evenly back-washing water and raw water occur when organic membrane were operated not consistently so that its process was unstable.

The operational condition of flux was set at $1 \mathrm{~m}^{3} / \mathrm{m}^{2} \cdot$ day (flux 1 ) to $4 \mathrm{~m}^{3} / \mathrm{m}^{2} \cdot$ day (flux 4 ). In order to achieve stable state of the plant, a flux rate was applied at $1 \mathrm{~m}^{3} / \mathrm{m}^{2}$.day for organic membrane and 2 $\mathrm{m}^{3} / \mathrm{m}^{2}$.day for ceramic membrane. Organic membrane is designed to be operated for a total of 48 cycles per day (at 1 cycle/30min per module). One cycle of the process consists of filtration ( $28 \mathrm{~min})$ and backwashing (2 min). Backwashing process include the application of $5 \mathrm{ppm} \mathrm{NaOCl}$ with air 
rinsing. Inorganic membrane process was operated for $120 \mathrm{~min}$ filtration and 108 second backwashing, and then a chemical enhanced backwash was conducted once a day. Backwashing process was conducted by putting the pressure of 5 bar with the use of the treated water filtered through ceramic membrane. Afterwards, the residues from the module were removed by putting the pressure of 2 bar air rinse.

Table 1. Properties of the MF membrane for lab and pilot-scale

\begin{tabular}{|l|l|l|l|}
\hline Scale & Lab & Pilot \\
\hline Material & Ceramic & $\begin{array}{l}\text { Polyvinylidene } \\
\text { fluoride (PVDF) }\end{array}$ & Ceramic \\
\hline Module size $(\mathrm{mm})$ & $\Phi 30 \cdot \mathrm{L} 100$ & $\Phi$ 216 $\mathrm{L} 2,160$ & $\Phi 216 \cdot \mathrm{L} \mathrm{2,338}$ \\
\hline Pore size $(\mu \mathrm{m})$ & 0.1 & 0.1 & 0.1 \\
\hline Membrane area $\left(\mathrm{m}^{2}\right)$ & 0.04 & 75 & 25 \\
\hline $\mathrm{pH}$ range & $1 \sim 14$ & $1 \sim 12$ & $1 \sim 14$ \\
\hline Pressure range $\left(\mathrm{kgf} / \mathrm{cm}^{2}\right)$ & 20 & 3 & 20 \\
\hline
\end{tabular}

Table 2. Properties of water samples

\begin{tabular}{|c|c|c|}
\hline Water sample & Characteristics & Value \\
\hline \multirow{4}{*}{ Raw water } & $\mathrm{pH}$ & 7.22 \\
\cline { 2 - 3 } & Turbidity $(\mathrm{NTU})$ & 0.669 \\
\cline { 2 - 3 } & $\mathrm{UV}_{254}\left(\mathrm{~cm}^{-1}\right)$ & 0.036 \\
\cline { 2 - 3 } & $\mathrm{SS}(\mathrm{mg} / \mathrm{L})$ & 10 \\
\cline { 2 - 3 } & $\mathrm{TOC}(\mathrm{mg} / \mathrm{L})$ & 2.43 \\
\cline { 2 - 3 } Back-washing & $\mathrm{DOC}(\mathrm{mg} / \mathrm{L})$ & 2.38 \\
\hline \multirow{7}{*}{ water } & $\mathrm{pH}$ & 6.97 \\
\cline { 2 - 3 } & Turbidity $(\mathrm{NTU})$ & 7.01 \\
\cline { 2 - 3 } & $\mathrm{UV} 254\left(\mathrm{~cm}{ }^{-1}\right)$ & 0.107 \\
\cline { 2 - 3 } & $\mathrm{SS}(\mathrm{mg} / \mathrm{L})$ & 20 \\
\cline { 2 - 3 } & TOC $(\mathrm{mg} / \mathrm{L})$ & 5.45 \\
\cline { 2 - 3 } & $\mathrm{DOC}(\mathrm{mg} / \mathrm{L})$ & 2.27 \\
\cline { 2 - 3 } & & \\
\hline
\end{tabular}

\subsection{Analytical devices}

A pH meter (F-74BW, HORIBA, Japan) was used for measuring pH. Total organic carbon (TOC), DOC and UV 254 were measured by a TOC analyzer (TOC-LCPH,Shimadzu, Japan) and UV-VIS spectrophotometer recording spectrometer (UV-1240, Shimadzu, Japan), respectively. A turbidity meter (Orion AQ4500, Thermo Scientific, Singapore) was adopted to measure turbidity, which recorded nephelometric turbidity unit (NTU). SUVA254 is the ratio of $U_{254}$ to the concentration of DOC in the water (Eq.(1)) [30].

$\operatorname{SUVA}_{254}(\mathrm{~L} / \mathrm{mg} \cdot \mathrm{m})=\mathrm{UV}\left(\mathrm{cm}^{-1}\right) \times 100(\mathrm{~cm} / \mathrm{m}) / \mathrm{DOC}(\mathrm{mg} / \mathrm{L})(1)$

\subsection{Jar test}

Jar test was conducted to derive the coagulation conditions by rapid mixing at $120 \mathrm{rpm}$ for 15 seconds, slow mixing at $20 \mathrm{rpm}$ for $15 \mathrm{~min}$, and precipitation after $10 \mathrm{~min}$. The concentration of coagulant was varied to find out the optimum dosage of coagulant. The coagulant used for the tests 
was A-PAC $10.6 \%$ (as $\mathrm{Al}_{2} \mathrm{O}_{3}$ ). After coagulant injection, turbidity, $\mathrm{UV}_{254}, \mathrm{TOC}$, and DOC were analyzed to determine optimal coagulation conditions.

\section{Results and Discussion}

\subsection{Lab-scale}

\subsubsection{Estimation of optimal dosage of coagulant (A-PAC) by jar test}

The results of jar test and the analysis of treated water quality include that, regardless of blending ratios, the dosage of coagulant (A-PAC 10.6\%) at 20 ppm showed stable efficient rates; therefore, the operational dosage of coagulant is $20 \mathrm{ppm}$.

Turbidity changes of treated water by coagulant doses and blending ratio were depicted to show that the lowest value for all blending conditions at $20 \mathrm{ppm}$ of coagulant was estimated to be $0.45 \mathrm{NTU}$ to $0.72 \mathrm{NTU}$ (Fig.1a). UV 254 was measured from $0.061 \mathrm{~cm}^{-1}$ to $0.076 \mathrm{~cm}^{-1}$ at the stage of initial blending. Fig. $1 \mathrm{~b}$ presents that $\mathrm{UV}_{254}$ at the unit of $0.02 \mathrm{~cm}^{-1}$ showed no significant changes from $15 \mathrm{ppm}$ to 30 ppm (Fig. 1b). Therefore, the dose of coagulant of $U_{254}$ is determined at $15 \mathrm{ppm}$ to $30 \mathrm{ppm}$. The initial value of DOC for blending was measured from $2.847 \mathrm{mg} / \mathrm{L}$ to $3.241 \mathrm{mg} / \mathrm{L}$. Fig.1c shows that the coagulant dose was reliably effective from $15 \mathrm{ppm}(1.646 \mathrm{mg} / \mathrm{L}$ to $2.040 \mathrm{mg} / \mathrm{L})$. However, the timing point of satisfying all the blending ratio was observed at $20 \mathrm{ppm}(1.647 \mathrm{mg} / \mathrm{L}$ to $1.954 \mathrm{mg} / \mathrm{L})$.

Consequently, the results imply that the optimal dose of coagulant is estimated at $20 \mathrm{ppm}$.
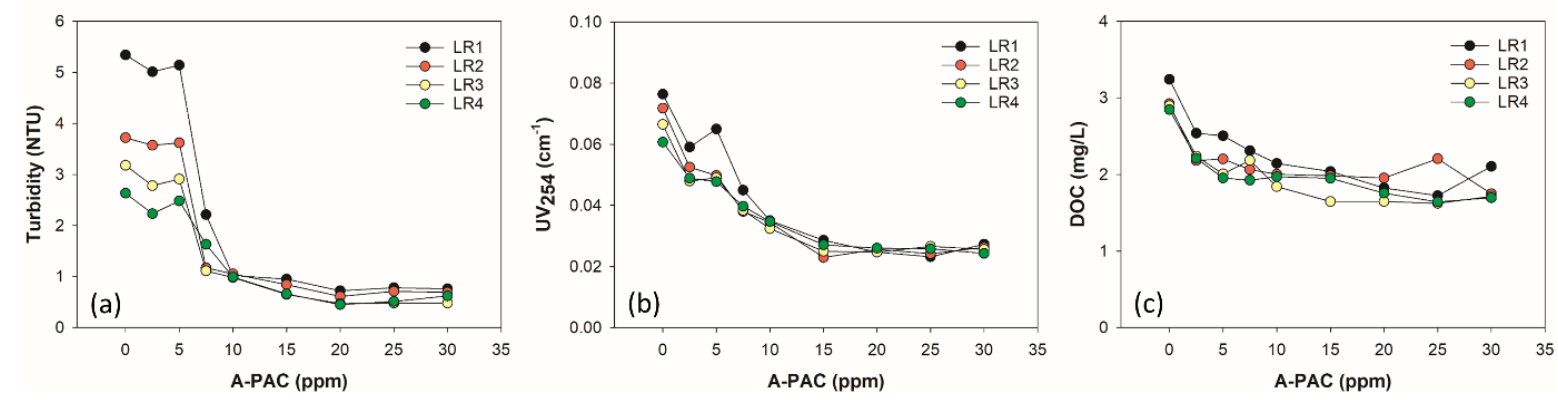

Figure. 1 Changes of (a) turbidity, (b) UV 254 , and (c) DOC of treated water by coagulant doses and blending ratio

\subsubsection{Estimation of optimal flux according to blending water}

The transmembrane pressure (TMP) of the lab-scale was measured with the results of the lab-scale test accordingly blending and flux. The result of LR1 showed 11.2 pka to 36.1 pka up to flux 3, but flux 3.5 was over 40 pka unlike other samples (Fig.2a). In addition, more than the result of flux 3.5 showed a tendency of TMP to increase in treatment time. In the case of LR2 and LR3, the pka below 40 was shown in all flux with 10.3 pka to 35.5 pka and 10.2 pka to 32.2 pka, respectively (Fig.2b, 2c). The TMP results of LR4 were 7.9 pka to 24.8 pka that in case of LR4(Fig.2d), this process was able to operate up to 4 fluxes without a sudden change in TMP, alike LR2 and LR3. Therefore, on the labscale basis, no significant change in the differential pressure was observed in the process except for the sample of LR1. Unless the blended raw water exceeds the water quality value of LR1, the process can be operated without any difficulty up to flux 4 . 

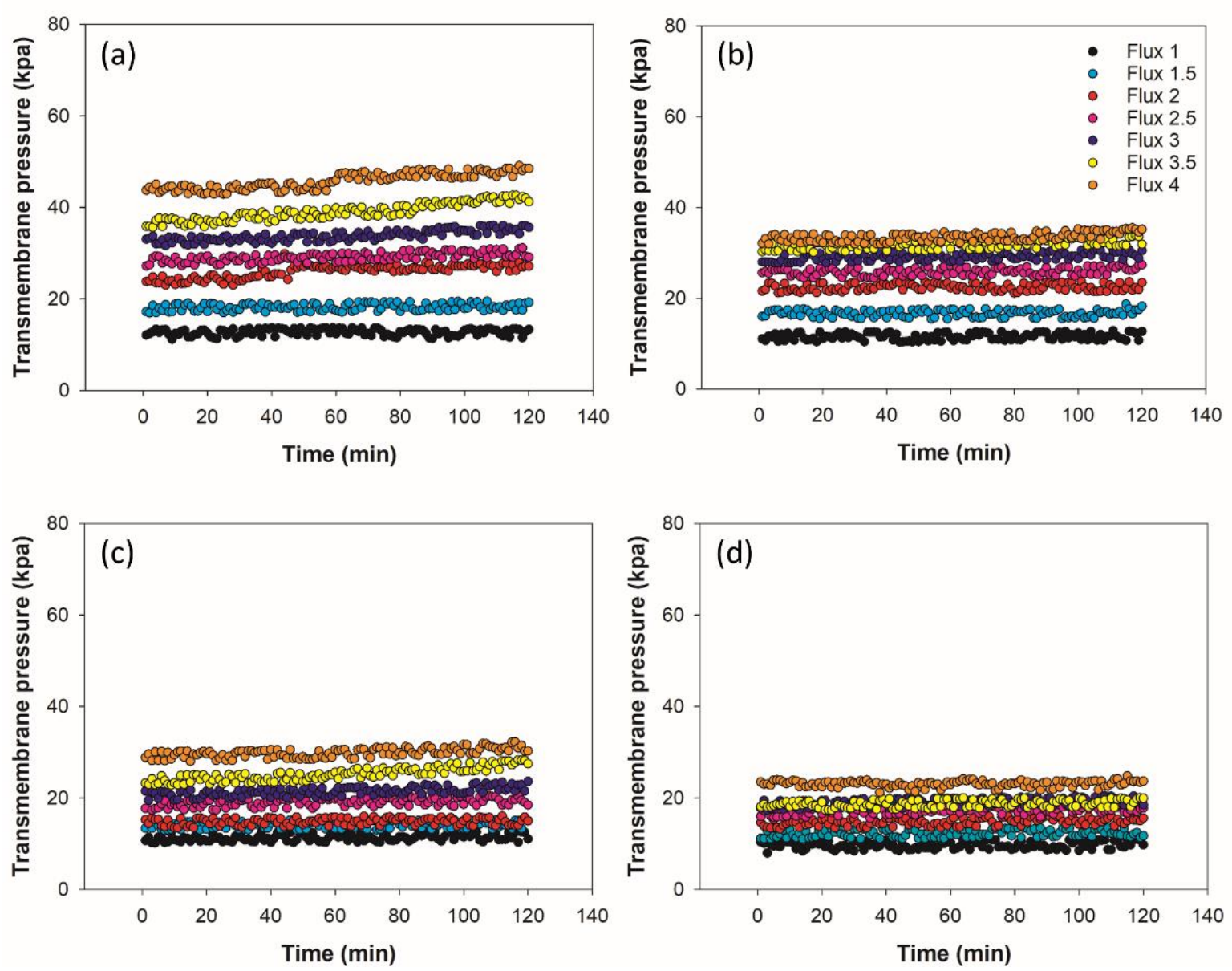

Figure. 2 Differential pressure according to blending ratio and flux on lab-scale: as each condition (a) LR1; (b) LR2; (c) LR3; (d) LR4

\subsubsection{Effects of blending ratio and flux on ceramic membrane}

Table 3 shows the properties of samples before and after the process. Table 4 presents the removal efficiencies according to the process. The $\mathrm{pH}$ of all treated sample ranged from 7.2 to 7.5 , which is similar to the initial value of 7.3 to 7.4 , and also all meet WTO drinking water standards of 6.5 to 8.0 [31]. The initial value of turbidity was formed from 1.41 NTU to 3.18 NTU. The all treated sample through the ceramic membrane showed a very low turbidity value of up to $0.068 \mathrm{NTU}$. In addition, the WTO drinking water standards satisfied 0.5 NTU [31].

The $\mathrm{pH}$ and turbidity showed no difference in blending and flux in all treated waters. The effect of the ceramic membrane was very low [32,33]. Turbidity was continually measured below 0.5 NTU for all experimental samples, which implies a superb turbidity removal capacity of the applied process. Turbidity treatment also showed very high removal efficiency (minimum: 96\% and maximum: 98\%). TOC of the blending sample showed $2.181 \mathrm{mg} / \mathrm{L}$ to $3.483 \mathrm{mg} / \mathrm{L}$, and the TOC of LR1 showed 3.483 $\mathrm{mg} / \mathrm{L}$ (Table3). For LR1, the flux was $2.942 \mathrm{mg} / \mathrm{L}$ at $2.712 \mathrm{mg} / \mathrm{L}$ and the treatment efficiency ranged from $15 \%$ to $21 \%$. TOC of LR2 was $3.199 \mathrm{mg} / \mathrm{L}$, and after treated sample of TOC increased $2.523 \mathrm{mg} / \mathrm{L}$ to $2.812 \mathrm{mg} / \mathrm{L}$ according to each flux. Treatment efficiency was also shown from $12 \%$ to $21 \%$ (Table4). For LR1 and LR2, the TOC did not show a significant difference in the effluent value (within $10 \%$ ) according to each flux. The TOC of LR3 and LR4 were $2.468 \mathrm{mg} / \mathrm{L}$ and $2.181 \mathrm{mg} / \mathrm{L}$, respectively. After treated LR3 of TOC was $1.968 \mathrm{mg} / \mathrm{L}$ to $1.998 \mathrm{mg} / \mathrm{L}$ according to each flux, and in case of LR4 was 1.723 $\mathrm{mg} / \mathrm{L}$ to $1.767 \mathrm{mg} / \mathrm{L}$ according to each flux. In order to continue to receive a low TOC of $2 \mathrm{mg} / \mathrm{L}$, the blending ratio should be maintained above LR3. 
The initial value of $\mathrm{UV}_{254}$ ranged from $0.041 \mathrm{~cm}^{-1}$ to $0.052 \mathrm{~cm}^{-1}$. The effluent had very low values (up to $0.023 \mathrm{~cm}^{-1}$ ). Treatment efficiency was also more than $50 \%$ in all conditions except for LR4. UV 254 showed low value due to the effect of the ceramic membrane [32]. The initial value of DOC showed $1.976 \mathrm{mg} / \mathrm{L}$ to $2.569 \mathrm{mg} / \mathrm{L}$. Except for LR1, the effluent concentrations mostly increased as the flux increased. All samples showed DOC values below $2 \mathrm{mg} / \mathrm{L}$ except for LR1. The initial DOC is important cause to determine DOC in the effluent. Thus, experimental data suggests that it is possible to obtain an optimum blending and flux.

Several research studies have demonstrated the effectiveness of the treatment of organic materials and $U_{254}$ through membrane treatment $[34,35]$. This study also showed the similar results. TOC, $\mathrm{UV}_{254}$, and DOC showed a sufficient reduction through this process. As UV 254 and DOC get lower that NOM was also expected to show a sufficient reduction [34,36].

The results shed light on that $\mathrm{pH}$ and turbidity met WTO standards in all processes. Turbidity also showed a high removal efficiency at least $96.9 \%$. Lab-scale processes require dilution above LR3 to achieve low TOC $(<2 \mathrm{mg} / \mathrm{L})$. However, the flux rate was not a significant factor. $\mathrm{UV}_{254}$ showed low values in all processes at a maximum $0.023 \mathrm{~cm}^{-1}$. In the case of DOC, the dilution factor should be more than LR2 to obtain a low DOC of less than $2 \mathrm{mg} / \mathrm{L}$. Therefore, in order to satisfy the required properties, the dilution ratio rather than the flux control should be more than LR2.

Table 3. Sample characteristics according to blending ratio and flux for lab-scale

\begin{tabular}{|c|c|c|c|c|c|c|c|}
\hline \multirow{2}{*}{\multicolumn{2}{|c|}{$\begin{array}{l}\text { Blending ratio* } \\
\text { and flux }\end{array}$}} & \multirow{3}{*}{$\begin{array}{l}\text { Sample } \\
\text { name } \\
\text { Lab-Run 1 (LR1) }\end{array}$} & \multicolumn{5}{|c|}{ Characteristics } \\
\hline & & & \multirow{2}{*}{\begin{tabular}{|l}
$\mathrm{pH}$ \\
7.4
\end{tabular}} & \multirow{2}{*}{$\begin{array}{l}\text { Turbidity } \\
\text { (NTU) }\end{array}$} & \multirow{2}{*}{$\begin{array}{l}\begin{array}{l}\text { TOC } \\
(\mathrm{mg} / \mathrm{L})\end{array} \\
3.483\end{array}$} & \multirow{2}{*}{$\begin{array}{l}\begin{array}{l}\mathrm{UV}_{254} \\
(\mathrm{~cm}-1)\end{array} \\
0.052\end{array}$} & \multirow{2}{*}{$\begin{array}{l}\begin{array}{l}\mathrm{DOC} \\
(\mathrm{mg} / \mathrm{L})\end{array} \\
2.569\end{array}$} \\
\hline Before & $\begin{array}{l}\text { Blending } \\
(2: 1)\end{array}$ & & & & & & \\
\hline & $\begin{array}{l}\text { Blending } \\
(4: 1)\end{array}$ & Lab-Run 2 (LR2) & 7.3 & 2.90 & 3.199 & 0.048 & 2.109 \\
\hline & $\begin{array}{l}\text { Blending } \\
(6: 1)\end{array}$ & Lab-Run 3 (LR3) & 7.3 & 1.78 & 2.468 & 0.045 & 2.285 \\
\hline & $\begin{array}{l}\text { Blending } \\
(8: 1)\end{array}$ & Lab-Run 4 (LR4) & 7.3 & 1.41 & 2.181 & 0.041 & 1.976 \\
\hline \multirow[t]{18}{*}{ After } & 1 flux & \multirow[t]{7}{*}{ LR1 } & 7.2 & 0.065 & 2.712 & 0.018 & 1.908 \\
\hline & 1.5 flux & & 7.2 & 0.040 & 2.744 & 0.016 & 2.045 \\
\hline & 2 flux & & 7.2 & 0.050 & 2.748 & 0.016 & 1.956 \\
\hline & 2.5 flux & & 7.2 & 0.045 & 2.804 & 0.018 & 2.050 \\
\hline & 3 flux & & 7.2 & 0.042 & 2.920 & 0.016 & 2.145 \\
\hline & 3.5 flux & & 7.2 & 0.057 & 2.934 & 0.018 & 1.998 \\
\hline & 4 flux & & 7.2 & 0.046 & 2.942 & 0.015 & 2.099 \\
\hline & 1 flux & \multirow[t]{7}{*}{ LR2 } & 7.3 & 0.068 & 2.523 & 0.015 & 1.510 \\
\hline & 1.5 flux & & 7.3 & 0.068 & 2.548 & 0.015 & 1.503 \\
\hline & 2 flux & & 7.3 & 0.048 & 2.618 & 0.015 & 1.658 \\
\hline & 2.5 flux & & 7.3 & 0.044 & 2.281 & 0.016 & 1.612 \\
\hline & 3 flux & & 7.3 & 0.045 & 2.720 & 0.016 & 1.652 \\
\hline & 3.5 flux & & 7.3 & 0.037 & 2.710 & 0.016 & 1.649 \\
\hline & 4 flux & & 7.3 & 0.047 & 2.812 & 0.017 & 1.643 \\
\hline & 1 flux & \multirow[t]{4}{*}{ LR3 } & 7.5 & 0.044 & 1.968 & 0.018 & 1.779 \\
\hline & 1.5 flux & & 7.5 & 0.047 & 1.998 & 0.018 & 1.814 \\
\hline & 2 flux & & 7.5 & 0.041 & 1.975 & 0.018 & 1.865 \\
\hline & 2.5 flux & & 7.5 & 0.039 & 1.965 & 0.019 & 1.879 \\
\hline
\end{tabular}




\begin{tabular}{|c|c|c|c|c|c|c|}
\hline 3 flux & & 7.5 & 0.037 & 1.979 & 0.018 & 1.811 \\
\hline 3.5 flux & & 7.5 & 0.038 & 1.971 & 0.019 & 1.712 \\
\hline 4 flux & & 7.5 & 0.043 & 1.988 & 0.018 & 1.738 \\
\hline 1 flux & LR4 & 7.5 & 0.043 & 1.723 & 0.020 & 1.540 \\
\hline 1.5 flux & & 7.5 & 0.040 & 1.735 & 0.023 & 1.548 \\
\hline 2 flux & & 7.4 & 0.039 & 1.754 & 0.021 & 1.541 \\
\hline 2.5 flux & & 7.5 & 0.036 & 1.767 & 0.020 & 1.602 \\
\hline 3 flux & & 7.5 & 0.041 & 1.757 & 0.019 & 1.588 \\
\hline 3.5 flux & & 7.5 & 0.041 & 1.760 & 0.018 & 1.614 \\
\hline 4 flux & & 7.5 & 0.036 & 1.759 & 0.019 & 1.632 \\
\hline
\end{tabular}

* Blending ratio: raw water mix back-washing from organic membrane treated water

Table 4. Sample of removal efficiency according to blending ratio and flux for lab-scale

\begin{tabular}{|c|c|c|c|c|c|}
\hline \multirow{2}{*}{\multicolumn{2}{|c|}{$\begin{array}{l}\text { Sample name and } \\
\text { each flux }\end{array}$}} & \multicolumn{4}{|c|}{ Characteristics } \\
\hline & & \multirow{2}{*}{$\begin{array}{l}\text { Turbidity (\%) } \\
97.9\end{array}$} & \multirow{2}{*}{$\begin{array}{l}\text { TOC (\%) } \\
22.1\end{array}$} & \multirow{2}{*}{$\begin{array}{l}U_{254}(\%) \\
65.3\end{array}$} & \multirow{2}{*}{$\begin{array}{l}\mathrm{DOC}(\%) \\
28.2 \\
\end{array}$} \\
\hline LR1 & Flux 1 & & & & \\
\hline & Flux 1.5 & 98.7 & 21.2 & 67.8 & 23.1 \\
\hline & Flux 2 & 98.4 & 21.1 & 67.6 & 26.4 \\
\hline & Flux 2.5 & 98.5 & 19.4 & 65.3 & 22.9 \\
\hline & Flux 3 & 98.6 & 16.1 & 68.2 & 19.3 \\
\hline & Flux 3.5 & 98.2 & 15.7 & 65.1 & 24.8 \\
\hline & Flux 4 & 98.5 & 15.5 & 69.4 & 21.0 \\
\hline \multirow[t]{7}{*}{ LR2 } & Flux 1 & 97.6 & 21.1 & 67.6 & 28.4 \\
\hline & Flux 1.5 & 97.6 & 20.3 & 68.7 & 28.7 \\
\hline & Flux 2 & 98.3 & 18.1 & 67.8 & 21.3 \\
\hline & Flux 2.5 & 98.4 & 16.1 & 66.6 & 23.5 \\
\hline & Flux 3 & 98.4 & 14.9 & 65.8 & 21.6 \\
\hline & Flux 3.5 & 98.7 & 15.2 & 66.4 & 21.8 \\
\hline & Flux 4 & 98.3 & 12.1 & 65.2 & 22.1 \\
\hline \multirow[t]{7}{*}{ LR3 } & Flux 1 & 97.5 & 20.2 & 60.2 & 22.1 \\
\hline & Flux 1.5 & 97.3 & 19.0 & 58.9 & 20.6 \\
\hline & Flux 2 & 97.7 & 19.9 & 59.3 & 18.3 \\
\hline & Flux 2.5 & 97.8 & 20.3 & 56.0 & 17.7 \\
\hline & Flux 3 & 97.9 & 19.8 & 58.7 & 20.7 \\
\hline & Flux 3.5 & 97.8 & 20.1 & 56.2 & 25.1 \\
\hline & Flux 4 & 97.5 & 19.4 & 59.8 & 23.9 \\
\hline \multirow[t]{7}{*}{ LR4 } & Flux 1 & 96.9 & 21.0 & 50.7 & 22.1 \\
\hline & Flux 1.5 & 97.1 & 20.4 & 43.4 & 21.6 \\
\hline & Flux 2 & 97.2 & 19.5 & 48.0 & 22.0 \\
\hline & Flux 2.5 & 97.4 & 18.9 & 51.2 & 18.9 \\
\hline & Flux 3 & 97.0 & 19.4 & 54.1 & 19.6 \\
\hline & Flux 3.5 & 97.0 & 19.3 & 56.5 & 18.3 \\
\hline & Flux 4 & 97.4 & 19.3 & 53.3 & 17.4 \\
\hline
\end{tabular}

3.1.4. SUVA254 reduction effect by blending and flux

The changes of $\mathrm{UV}_{254}$ and DOC according to blending and flux were evaluated and the changes of SUVA $_{254}$ are summarized in Table 5. The SUVA 254 initial value of LR1 was $2.02 \mathrm{~L} / \mathrm{mg} \cdot \mathrm{m}$. The test 
resulted in $0.71 \mathrm{~L} / \mathrm{mg} \cdot \mathrm{m}$ at $0.94 \mathrm{~L} / \mathrm{mg} \cdot \mathrm{m}$ depending on the flux after membrane treatment and all outcomes were below $1.00 \mathrm{~L} / \mathrm{mg} \cdot \mathrm{m}$. LB2 (SUVA 254 of $2.28 \mathrm{~L} / \mathrm{mg} \cdot \mathrm{m}$ ) generated the outcome of 1.03 $\mathrm{L} / \mathrm{mg} \cdot \mathrm{m}$ at $0.97 \mathrm{~L} / \mathrm{mg} \cdot \mathrm{m}$ depending on the flux after treatment, which all result were below 1.00 $\mathrm{L} / \mathrm{mg} \cdot \mathrm{m}$ except for4flux. In case of $\mathrm{LR} 3, \mathrm{SUVA}_{254}$ value was $1.97 \mathrm{~L} / \mathrm{mg} \cdot \mathrm{m}$, and after treatment the results were $1.03 \mathrm{~L} / \mathrm{mg} \cdot \mathrm{m}$ at $0.96 \mathrm{~L} / \mathrm{mg} \cdot \mathrm{m}$ depending on the flux. In addition, all results showed the level of below $1.00 \mathrm{~L} / \mathrm{mg} \cdot \mathrm{m}$ at all flux except flux 4 , alike LR2. For LR4 the SUVA254 showed an initial value of $2.07 \mathrm{~L} / \mathrm{mg} \cdot \mathrm{m}$. However, the results were $1.12 \mathrm{~L} / \mathrm{mg} \cdot \mathrm{m}$ to $1.49 \mathrm{~L} / \mathrm{mg} \cdot \mathrm{m}$ depending on the flux and the value were $1.00 \mathrm{~L} / \mathrm{mg} \cdot \mathrm{m}$ or more at all fluxes. Removal efficiency was also the lowest $28.2 \%$.

LR1 was possible at all fluxes to obtain low $\operatorname{SUVA}_{254}(<1 \mathrm{~L} / \mathrm{mg} \cdot \mathrm{m})$. The other samples (LR2 and LR3) require less than 3.5 fluxes for obtainment of low $\operatorname{SUVA}_{254}(<1 \mathrm{~L} / \mathrm{mg} \cdot \mathrm{m})$.

SUVA $_{254}$ is a very useful parameter to provide information on the chemical properties and process effectiveness of organic materials [37]. SUVA254 is also directly related to the aromatic carbon content of organic matter [38]. SUVA254, which represents these indicators, confirmed a significant reduction through this process. Thus, ceramic membranes are a sufficient process to reduce the NOM of drinking water [39], and through proper blending and flux control of raw water, this process can obtain low SUVA254 continuously.

Table 5. Removal effect and efficiency of SUVA254 according to mixing ratio and flux

\begin{tabular}{|c|c|c|c|c|c|c|c|}
\hline \multicolumn{2}{|c|}{$\begin{array}{l}\text { Sample name } \\
\text { and each flux }\end{array}$} & \multirow{2}{*}{$\begin{array}{l}\mathrm{SUVA}_{254} \\
(\mathrm{~L} / \mathrm{mg} \cdot \mathrm{m}) \\
2.02\end{array}$} & \multirow{2}{*}{$\begin{array}{l}\text { Removal } \\
\text { efficiency (\%) } \\
-\end{array}$} & \multicolumn{2}{|c|}{$\begin{array}{l}\text { Sample name } \\
\text { and each flux }\end{array}$} & \multirow{2}{*}{$\begin{array}{l}\mathrm{SUVA}_{254} \\
(\mathrm{~L} / \mathrm{mg} \cdot \mathrm{m}) \\
2.28\end{array}$} & \multirow{2}{*}{$\begin{array}{l}\text { Removal } \\
\text { efficiency (\%) } \\
-\end{array}$} \\
\hline LR1 & $\begin{array}{l}\text { Raw } \\
\text { water }\end{array}$ & & & \multirow[t]{8}{*}{ LR2 } & $\begin{array}{l}\text { Raw } \\
\text { water }\end{array}$ & & \\
\hline & Flux 1 & 0.94 & 53.3 & & Flux 1 & 0.99 & 56.4 \\
\hline & Flux 1.5 & 0.78 & 61.3 & & Flux 1.5 & 1.00 & 56.2 \\
\hline & Flux 2 & 0.82 & 59.5 & & Flux 2 & 0.90 & 60.3 \\
\hline & Flux 2.5 & 0.88 & 56.5 & & Flux 2.5 & 0.99 & 56.5 \\
\hline & Flux 3 & 0.75 & 63.1 & & Flux 3 & 0.97 & 57.5 \\
\hline & Flux 3.5 & 0.90 & 55.4 & & Flux 3.5 & 0.97 & 57.4 \\
\hline & Flux 4 & 0.71 & 64.6 & & Flux 4 & 1.03 & 54.6 \\
\hline \multirow[t]{8}{*}{ LR3 } & $\begin{array}{l}\text { Raw } \\
\text { water }\end{array}$ & 1.97 & - & \multirow[t]{8}{*}{ LR4 } & $\begin{array}{l}\text { Raw } \\
\text { water }\end{array}$ & 2.07 & - \\
\hline & Flux 1 & 0.99 & 56.4 & & Flux 1 & 1.30 & 37.3 \\
\hline & Flux 1.5 & 1.00 & 56.2 & & Flux 1.5 & 1.49 & 28.2 \\
\hline & Flux 2 & 0.96 & 60.3 & & Flux 2 & 1.36 & 34.2 \\
\hline & Flux 2.5 & 0.99 & 56.5 & & Flux 2.5 & 1.25 & 39.7 \\
\hline & Flux 3 & 0.97 & 57.5 & & Flux 3 & 1.20 & 42.2 \\
\hline & Flux 3.5 & 0.97 & 57.4 & & Flux 3.5 & 1.12 & 46.1 \\
\hline & Flux 4 & 1.03 & 54.6 & & Flux 4 & 1.16 & 43.8 \\
\hline
\end{tabular}

\subsection{Pilot-scale}

\subsubsection{Operational process of the plant and conditions of differential pressures}

The plant-scale test was designed to be operated according to the operating conditions obtained through the lab-scale process. However, as to making samples, certain proportion of samples resulted from lab-scale were not exactly applied to the pilot-scale, and a constant ratio were maintained as much as possible. The blending ratios and characteristics of the pilot scale samples was addressed in Table 6 . When also changing the operating conditions, cleaning-in-place was performed to make the initial condition same to the lab-scale. Afterwards, the treated water characteristics were analyzed under conditions of stable operation. 
The optimal dosage of coagulant was operated at $20 \mathrm{ppm}$ which was obtained from the lab-scale test. The operating pressure of the inorganic membrane was applied at $20 \mathrm{kgf} / \mathrm{cm}^{2}(1,961.33 \mathrm{kPa})$, but the maximum possible pressure was set to $1.5 \mathrm{kgf} / \mathrm{cm}^{2}(147.1 \mathrm{kPa})$ for maintaining stable condition in operating actual process. Priority PR5 with the least differential pressure was used for flux selection. As a result, (Fig. 3a), pressure was close to $100 \mathrm{kPa}$ in flux 4 . Therefore, in this study, flux was chosen as $2 \mathrm{~m}^{3} / \mathrm{m}^{2}$.day (flux 2) for stable and sustainable operation of membrane process. Employing the selected flux, a differential pressure test was conducted to check the differential pressure of each sample. As a result (Fig. 3b), all conditions were possible to ensure stable operation not exceeding 50 $\mathrm{kPa}$.
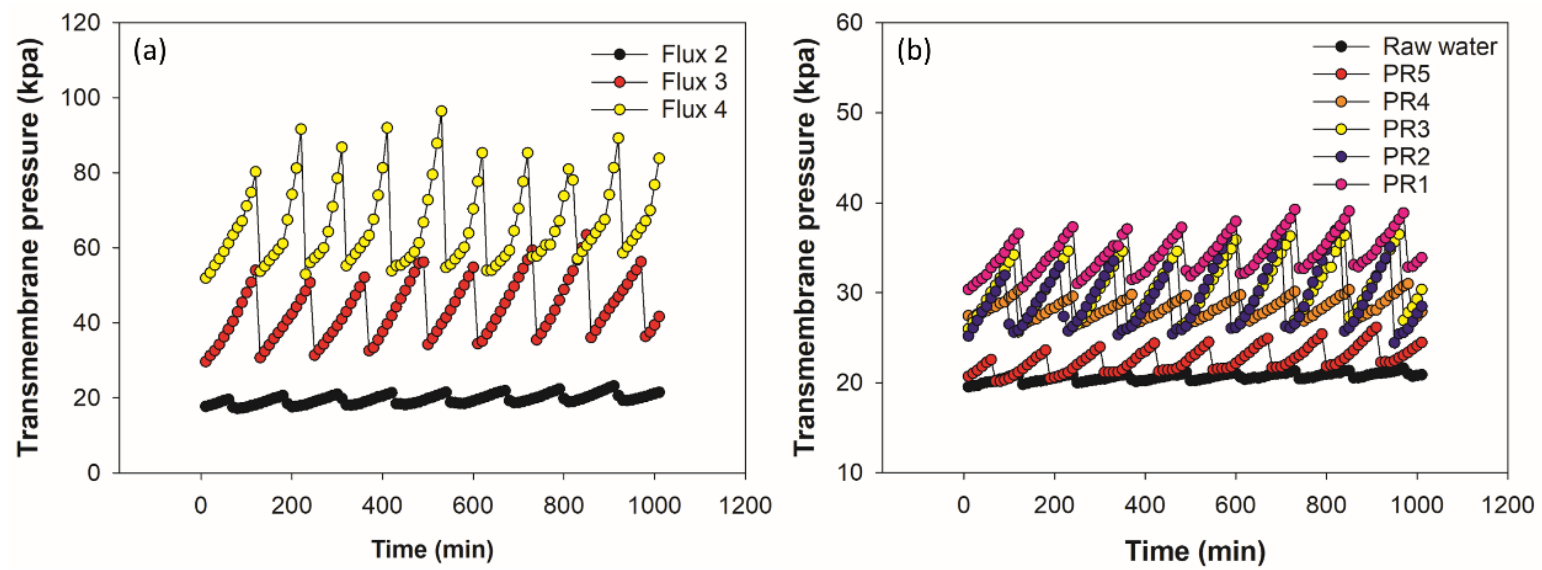

Figure. 2 Differential pressure depending on the conditions in the pilot-plant process: (a) differential pressure of PR5 depending on flux; (b) Differential pressure according to flux 2 and blending ratio

\subsubsection{Effect of blending ratio on pilot-scale}

Table 6 shows the water quality values before and after pilot process. Turbidity was very low at 0.001 NTU under all conditions. UV 254 showed mostly constant blending sample values $(0.044$ to $0.054 \mathrm{~cm}-$ 1 ) and then, treated water also showed relatively constant values $(0.021$ to $0.026 \mathrm{~cm}-1)$. However, the lowest value was $0.021 \mathrm{~cm}-1$ in PR3 and PR5. The initial value of DOC was $2.59 \mathrm{mg} / \mathrm{L}$ at $2.89 \mathrm{mg} / \mathrm{L}$ and after treatment DOC were showed at the level of $1.41 \mathrm{mg} / \mathrm{L}$ to $2.19 \mathrm{mg} / \mathrm{L}$. Showing the lowest value in PR3 $(1.41 \mathrm{mg} / \mathrm{L})$. The initial value of $\mathrm{SUVA}_{254}$ shows a value of $1.57 \mathrm{~L} / \mathrm{mg} \cdot \mathrm{m}$ to 2.06 $\mathrm{L} / \mathrm{mg} \cdot \mathrm{m}$, and the value of SUVA 254 after treatment is $1.19 \mathrm{~L} / \mathrm{mg} \cdot \mathrm{m}$ to $1.59 \mathrm{~L} / \mathrm{mg} \cdot \mathrm{m}$, which is 1.3 times lower than before treatment. Therefore, the ceramic process is regarded as effective in reducing disinfection by-products.

Overall, the blending sample is expected to be stable and continuous operation when operating with flux 2 and PR3 during the pilot-scale process of ceramic membrane.

Table 6. Sample characteristics with blending ratio and flux for pilot-scale

\begin{tabular}{|c|c|c|c|c|c|c|c|}
\hline \multirow{2}{*}{\multicolumn{2}{|c|}{$\begin{array}{l}\text { Blending ratio* } \\
\text { and flux }\end{array}$}} & \multirow{3}{*}{$\begin{array}{l}\text { Sample } \\
\text { name }\end{array}$} & \multicolumn{5}{|c|}{ Characteristics } \\
\hline & & & \multirow{2}{*}{$\begin{array}{c}\mathrm{pH} \\
7.3\end{array}$} & \multirow{2}{*}{$\begin{array}{l}\text { Turbidity } \\
\text { (NTU) } \\
4.44\end{array}$} & \multirow{2}{*}{$\begin{array}{l}\mathrm{UV}_{254} \\
(\mathrm{~cm}-1) \\
0.052\end{array}$} & \multirow{2}{*}{$\begin{array}{l}\begin{array}{l}\mathrm{DOC} \\
(\mathrm{mg} / \mathrm{L})\end{array} \\
2.59\end{array}$} & \multirow{2}{*}{$\begin{array}{l}\mathrm{SUVA}_{254} \\
(\mathrm{~L} / \mathrm{m}-\mathrm{mg}) \\
2.01\end{array}$} \\
\hline \multirow[t]{4}{*}{ Before } & $\begin{array}{l}\text { Blending } \\
(3.7: 1)\end{array}$ & & & & & & \\
\hline & $\begin{array}{l}\text { Blending } \\
(4.6: 1)\end{array}$ & $\begin{array}{l}\text { Pilot-Run } 2 \\
\text { (PR2) }\end{array}$ & 7.1 & 4.20 & 0.054 & 2.62 & 2.06 \\
\hline & $\begin{array}{l}\text { Blending } \\
(6.0: 1)\end{array}$ & $\begin{array}{l}\text { Pilot-Run } 3 \\
\text { (PR3) }\end{array}$ & 7.1 & 2.34 & 0.047 & 2.75 & 1.71 \\
\hline & $\begin{array}{l}\text { Blending } \\
(6.7: 1)\end{array}$ & $\begin{array}{l}\text { Pilot-Run } 4 \\
\text { (PR4) }\end{array}$ & 7.0 & 1.98 & 0.044 & 2.80 & 1.57 \\
\hline
\end{tabular}




\begin{tabular}{|l|l|l|l|l|l|l|l|}
\hline & $\begin{array}{l}\text { Blending } \\
(7.5: 1)\end{array}$ & $\begin{array}{l}\text { Pilot-Run 5 } \\
\text { (PR5) }\end{array}$ & 7.1 & 0.91 & 0.046 & 2.65 & 1.74 \\
\hline \multirow{3}{*}{ After } & \multirow{2}{*}{ Flux 2 } & PR1 & 7.6 & 0.001 & 0.025 & 1.63 & 1.53 \\
\cline { 3 - 8 } & & PR2 & 7.2 & 0.001 & 0.024 & 1.80 & 1.33 \\
\cline { 3 - 8 } & & PR3 & 7.2 & 0.001 & 0.021 & 1.41 & 1.49 \\
\cline { 3 - 8 } & & PR4 & 7.2 & 0.001 & 0.026 & 2.19 & 1.19 \\
\cline { 3 - 8 } & & PR5 & 7.2 & 0.001 & 0.021 & 1.64 & 1.28 \\
\hline
\end{tabular}

* Blending ratio: raw water mix back-washing from organic membrane treated water

\subsubsection{Increased recovery efficiency by combination process}

Table 7 shows the recovery efficiency of organic membrane process and combination process applied to raw water treatment. The recovery rate was $92.1 \%$ when operating with flux 1 in the organic process. The recovery efficiency of the combination process according to the blending ratio was $96.2 \%$ $\sim 98.4 \%$. Recovery data analysis showed the highest recovery when the blending ratio was 6.0:1 (PR3). The low recovery efficiency $(92.1 \%)$ when the organic membrane was operated alone, but the combination process was used, the recovery efficiency can be greatly increased. Thus, by adjusting the blending ratio and flux, the overall recovery efficiency of the membrane filtration system could be operated at more than $98 \%$. 
Table 7. Recovery efficiency of single process and combination process on pilot-plant

\begin{tabular}{|c|c|c|c|c|c|c|c|c|c|}
\hline Process & $\begin{array}{l}\text { Sample } \\
\text { name }\end{array}$ & \multicolumn{2}{|c|}{ Treated water $(\mathrm{m} 3 / \mathrm{d})$} & \multicolumn{2}{|c|}{ Backwash water (m3/d) } & \multicolumn{2}{|c|}{ Drain water $(\mathrm{m} 3 / \mathrm{d})$} & \multicolumn{2}{|c|}{ Recovery efficiency* $(\%)$} \\
\hline Organic process & Raw & \multicolumn{2}{|l|}{137.7} & \multicolumn{2}{|l|}{7.4} & \multicolumn{2}{|l|}{3.8} & \multicolumn{2}{|l|}{92.1} \\
\hline Process & $\begin{array}{l}\text { Sample } \\
\text { name }\end{array}$ & $\begin{array}{l}\text { Treated } \\
\text { water } \\
\text { (organic) } \\
(\mathrm{m} 3 / \mathrm{d})\end{array}$ & $\begin{array}{l}\text { Treated } \\
\text { water } \\
\text { (ceramic) } \\
(\mathrm{m} 3 / \mathrm{d})\end{array}$ & $\begin{array}{l}\text { Backwash } \\
\text { water } \\
\text { (organic) } \\
(\mathrm{m} 3 / \mathrm{d}) \\
\end{array}$ & $\begin{array}{l}\text { Backwash } \\
\text { (water } \\
\text { ceramic) } \\
(\mathrm{m} 3 / \mathrm{d})\end{array}$ & $\begin{array}{l}\text { Raw } \\
\text { water } \\
\text { (organic) } \\
(\mathrm{m} 3 / \mathrm{d}) \\
\end{array}$ & $\begin{array}{l}\text { Drain } \\
\text { water } \\
\text { (organic) } \\
(\mathrm{m} 3 / \mathrm{d})\end{array}$ & $\begin{array}{l}\text { Raw water } \\
+ \text { Drain water } \\
\text { (organic) } \\
(\mathrm{m} 3 / \mathrm{d})\end{array}$ & $\begin{array}{l}\text { Recovery } \\
\text { efficiency } \\
(\%)\end{array}$ \\
\hline \multirow{5}{*}{$\begin{array}{l}\text { Combination } \\
\text { processes } \\
\text { (organic \& ceramic) }\end{array}$} & PR1 & \multirow[t]{5}{*}{137.7} & 119.4 & \multirow[t]{5}{*}{7.4} & \multirow[t]{5}{*}{0.6} & \multirow[t]{5}{*}{141.5} & \multirow[t]{5}{*}{3.8} & 124.1 & 97.9 \\
\hline & PR2 & & 117.4 & & & & & 121.1 & 98.3 \\
\hline & PR3 & & 118.3 & & & & & 121.8 & 98.4 \\
\hline & PR4 & & 121.7 & & & & & 130.9 & 96.2 \\
\hline & PR5 & & 118.5 & & & & & 122.9 & 98.0 \\
\hline
\end{tabular}

* Recovery efficiency (\%): (treated water - backwash water) / (treated water + drain water) 100

** The raw water was different for each process depending on the blending ratio during process operation.

*** Recovery efficiency (\%): (treated water (ceramic) + treated water (organic) - backwash water (organic) - backwash (water ceramic)) / (raw water (organic) + raw water + drain water (organic) ${ }^{* *}$ - backwash water (organic) - drain water (organic)) 


\section{Conclusion}

This study found out the effects of ceramic membranes and the optimal blending and fluxes through the lab and pilot-scale. The optimal dosage of coagulant was estimated at 20 ppm through the lab-scale test. It also showed the best treatment at blending 4:1, but the effect of flux was not significant. The optimum conditions of the pilot process considering the differential pressure and treated water quality were flux 2 and blending 6:1. With employing the outcomes, the operation of ceramic membrane filtration at the pilot-scale resulted in a significant reduction of the membrane load and obtained clean water quality. In addition, SUVA 254 values were very low. Accordingly, this result implied that the concentration of humic substances was relatively low among organic materials. The recovery efficiency was $92.1 \%$ in a single process, but a high recovery efficiency of up to $98.4 \%$ in the combined process of organic and ceramic membranes. The implication of the results include that the combination process has an excellent effect and a recovery efficiency in the treatment of the blending samples.

Author Contributions: Sung-joon Kim overall control this paper.

Conflicts of Interest: The author declare no conflict of interest.

\section{References}

1. Jiang, S.; Li, Y.; Ladewig, B.P. A review of reverse osmosis membrane fouling and control strategies. Science of The Total Environment 2017, 595, 567-583.

2. Yao, M.; Yan, D.; Kabat, P.; Huang, H.; Hutjes, R.W.; Werners, S.E. Analysing monthly sectorial water use and its influence on salt intrusion induced water shortage in urbanized deltas. Sustainable Cities Society 2016, 26, 255-263.

3. Avrin, A.-P.; He, G.; Kammen, D.M. Assessing the impacts of nuclear desalination and geoengineering to address China's water shortages. Desalination 2015, 360, 1-7.

4. Garcia-Cuerva, L.; Berglund, E.Z.; Binder, A.R. Public perceptions of water shortages, conservation behaviors, and support for water reuse in the US. Resources, Conservation Recycling 2016, 113, 106-115.

5. Bartman, A.R.; Lyster, E.; Rallo, R.; Christofides, P.D.; Cohen, Y. Mineral scale monitoring for reverse osmosis desalination via real-time membrane surface image analysis. Desalination 2011, 273, 64-71.

6. Gu, H.; Bartman, A.R.; Uchymiak, M.; Christofides, P.D.; Cohen, Y. Self-adaptive feed flow reversal operation of reverse osmosis desalination. Desalination 2013, 308, 63-72.

7. Humbert, H.; Gallard, H.; Croué, J.-P. A polishing hybrid AER/UF membrane process for the treatment of a high DOC content surface water. Water research 2012, 46, 1093-1100.

8. Neubrand, W.; Vogler, S.; Ernst, M.; Jekel, M. Lab and pilot scale investigations on membrane fouling during the ultrafiltration of surface water. Desalination 2010, 250, 968-972.

9. Bu, F.; Gao, B.; Yue, Q.; Liu, C.; Wang, W.; Shen, X. The Combination of Coagulation and Adsorption for Controlling Ultra-Filtration Membrane Fouling in Water Treatment. Water 2019, 11, 90.

10. Karanfil, T.; Erdogan, I.; Schlautman, M. The impact of filtrate turbidity on UV254 and SUVA254 determinations. Journal-American Water Works Association 2005, 97, 125-136.

11. Muthuraman, G.; Sasikala, S. Removal of turbidity from drinking water using natural coagulants. Journal of Industrial Engineering Chemistry 2014, 20, 1727-1731. 
12. Lin, L.; Feng, C.; Lopez, R.; Coronell, O. Identifying facile and accurate methods to measure the thickness of the active layers of thin-film composite membranes-A comparison of seven characterization techniques. Journal of Membrane Science 2016, 498, 167-179.

13. Gao, W.; Liang, H.; Ma, J.; Han, M.; Chen, Z.-1.; Han, Z.-s.; Li, G.-b. Membrane fouling control in ultrafiltration technology for drinking water production: a review. Desalination 2011, 272, 1-8.

14. Wang, X.; Anctil, A.; Masten, S. Energy consumption and environmental impact analysis of ozonation catalytic membrane filtration system for water treatment. Environmental Engineering Science 2019, 36, 149-157.

15. Bottino, A.; Capannelli, C.; Del Borghi, A.; Colombino, M.; Conio, O. Water treatment for drinking purpose: ceramic microfiltration application. Desalination 2001, 141, 75-79.

16. Li, L.; Visvanathan, C. Membrane technology for surface water treatment: advancement from microfiltration to membrane bioreactor. J Reviews in Environmental Science Bio/Technology 2017, 16, 737760.

17. Ma, B.; Xue, W.; Hu, C.; Liu, H.; Qu, J.; Li, L. Characteristics of microplastic removal via coagulation and ultrafiltration during drinking water treatment. J Chemical Engineering Journal 2019, 359, 159-167.

18. Chao, K.-P.; Wang, V.-S.; Hong, G.-M. Development of an in-cell SPME method to determine the chemical resistance of polymeric membranes to permeation by organic solvents. Polymer Testing 2012, 31, 1-6.

19. de Souza Araki, M.; de Morais Coutinho, C.; Gonçalves, L.A.; Viotto, L.A. Solvent permeability in commercial ultrafiltration polymeric membranes and evaluation of the structural and chemical stability towards hexane. Separation Purification Technology 2010, 71, 13-21.

20. Vatai, G.N.; Krstic, D.M.; Koris, A.K.; Gáspár, I.L.; Tekic, M.N. Ultrafiltration of oil-in-water emulsion: Comparison of ceramic and polymeric membranes. Desalination Water Treatment 2009, 3, 162-168.

21. Kimura, K.; Tanaka, K.; Watanabe, Y. Microfiltration of different surface waters with/without coagulation: Clear correlations between membrane fouling and hydrophilic biopolymers. Water Research 2014, 49, 434-443.

22. Almandoz, M.; Pagliero, C.L.; Ochoa, N.A.; Marchese, J. Composite ceramic membranes from natural aluminosilicates for microfiltration applications. Ceramics International 2015, 41, 5621-5633.

23. Dong, Y.; Lin, B.; Zhou, J.-e.; Zhang, X.; Ling, Y.; Liu, X.; Meng, G.; Hampshire, S. Corrosion resistance characterization of porous alumina membrane supports. Materials Characterization 2011, 62, 409-418.

24. Kujawski, W.; Kujawa, J.; Wierzbowska, E.; Cerneaux, S.; Bryjak, M.; Kujawski, J. Influence of hydrophobization conditions and ceramic membranes pore size on their properties in vacuum membrane distillation of water-organic solvent mixtures. Journal of Membrane Science 2016, 499, 442-451.

25. Van Gestel, T.; Vandecasteele, C.; Buekenhoudt, A.; Dotremont, C.; Luyten, J.; Van der Bruggen, B.; Maes, G. Corrosion properties of alumina and titania NF membranes. Journal of membrane science 2003, 214, 21-29.

26. Wu, T.; Wang, N.; Li, J.; Wang, L.; Zhang, W.; Zhang, G.; Ji, S. Tubular thermal crosslinkedPEBA/ceramic membrane for aromatic/aliphatic pervaporation. Journal of Membrane Science 2015, 486, $1-9$.

27. Peng, W.; Mayorga, R.V.; Imran, S. A robust optimization approach for real-time multiple source drinking water blending problem. Journal of water supply: Research Technology-AQUA 2012, 61, 111-122. 
28. Imran, S.A.; Dietz, J.D.; Mutoti, G.; Xiao, W.; Taylor, J.S.; Desai, V. Optimizing source water blends for corrosion and residual control in distribution systems. Journal-American Water Works Association 2006, 98, 107-115.

29. Fan, Z.; Wang, Z.; Sun, N.; Wang, J.; Wang, S. Performance improvement of polysulfone ultrafiltration membrane by blending with polyaniline nanofibers. Journal of Membrane Science 2008, 320, 363-371.

30. Kim, Y.-B.; Ahn, J.-H. Changes of absorption spectra, SUVA 254, and color in treating landfill leachate using microwave-assisted persulfate oxidation. Korean Journal of Chemical Engineering 2017, 34, 19801984.

31. Haydar, S.; Arshad, M.; Aziz, J. Evaluation of drinking water quality in urban areas of Pakistan: A case study of Southern Lahore. Pakistan Journal of Engineering Applied Sciences

2016.

32. Lee, H.C.; Park, J.Y.; Yoon, D.-Y. Advanced water treatment of high turbid source by hybrid module of ceramic microfiltration and activated carbon adsorption: Effect of organic/inorganic materials. Korean Journal of Chemical Engineering 2009, 26, 697-701.

33. Meyn, T.; Leiknes, T. Comparison of optional process configurations and operating conditions for ceramic membrane MF coupled with coagulation/flocculation pre-treatment for the removal of NOM in drinking water production. ournal of Water Supply: Research Technology-AQUA 2010, 59, 81-91.

34. Rockey, C.; Metcalfe, D.; Galjaard, G.; Shorney-Darby, H.; Zheng, J. Ceramic microfiltration; a novel and compact process for the treatment of surface water. Water Science Technology: Water Supply 2018, 18, 2035-2043.

35. Zhu, H.; Wen, X.; Huang, X. Characterization of membrane fouling in a microfiltration ceramic membrane system treating secondary effluent. Desalination 2012, 284, 324-331.

36. Metsämuuronen, S.; Sillanpää, M.; Bhatnagar, A.; Mänttäri, M. Natural organic matter removal from drinking water by membrane technology. Separation Purification Reviews 2014, 43, 1-61.

37. Comstock, S.E.; Boyer, T.H.; Graf, K.C.; Townsend, T.G. Effect of landfill characteristics on leachate organic matter properties and coagulation treatability. Chemosphere 2010, 81, 976-983.

38. Yapsakli, K.; Cecen, F. Effect of type of granular activated carbon on DOC biodegradation in biological activated carbon filters. Process Biochemistry 2010, 45, 355-362.

39. Kim, K.-J.; Jang, A. Presence of Fe-Al binary oxide adsorbent cake layer in ceramic membrane filtration and their impact for removal of HA and BSA. Chemosphere 2018, 196, 440-452. 